ORIGINAL ARTICLE

\title{
Profile of Ameloblastoma from a Retrospective Study in Jakarta, Indonesia
}

\author{
Rusdiana, Sirera Uvie Sandini, Evy Eida Vitria, Teguh Iman Santoso \\ Department of Oral Surgery, Faculty of Dentistry, Universitas Indonesia, Jakarta 10430, Indonesia \\ Corresponding e-mail to: evy_eida@yahoo.com
}

\begin{abstract}
Ameloblastoma is an odontogenic tumor occurring mostly in mandible. Objective: the purpose of the study was to find out the distribution and frequency of the most common histopathological type and pattern of ameloblastoma, the percentage of ameloblastoma according to gender and histopathological types of ameloblastoma related to gender. Methods: This research was a quantitative analysiswith descriptive retrospective design. This study used secondary data taken from medical records at Oral and Maxillofacial Surgery Clinic of Cipto Mangunkusumo General Hospital Jakarta in the period of January 2002-July 2008. The relationship between age or gender and histopathological types of ameloblastoma was statistically assessed. Results: From data of ameloblastoma patients that have been collected as many as 66 cases; it was found that $31-50$ years old age group had the highest percentages of occurrence among other age groups that was $53 \%$ from all cases. There are slight differences between women and men in ameloblastoma cases. The incidence was higher in women (37 cases, $56.1 \%$ ) than in men (29 cases, $43.9 \%$ ) and the histopathological type found most often was plexiform type as many as $31.8 \%$ from all cases. Conclusion: Ameloblastoma presented in adult period, more frequent in women than men, and were predominantly plexiform.
\end{abstract}

\begin{abstract}
ABSTRAK
Profil ameloblastoma dari sebuah penelitian retrospektif di Jakarta, Indonesia. Ameloblastoma adalah tumor odontogenik yang sering terjadi pada mandibula. Tujuan: Penelitian ini bertujuan untuk mengetahui distribusi frekuensi dari tipe dan pola histopatologis ameloblastoma yang paling umum, persentase timbulnya ameloblastoma menurut jenis kelamin, dan tipe histopatologis ameloblastoma terkait jenis kelamin. Metode: Penelitian ini merupakan penelitian kuantitatif dengan desain retrospektif deskriptif. Penelitian ini menggunakan data sekunder yang diperoleh dari rekam medik klinik Bedah Mulut di Rumah Sakit Umum Cipto Mangunkusumo Jakarta, pada periode Januari 2002-Juli 2008. Penelitian ini dilakukan untuk mengetahui frekuensi tipe histopatologis. Hubungan antara usia atau jenis kelamin dan tipe histopatologi ameloblastoma dianalisis secara statistik. Hasil: Dari data 66 kasus pasien ameloblastoma yang terkumpul, ditemukan bahwa kelompok umur 31-50 tahun memiliki persentase kemunculan terbesar dibanding kelompok umur lain, yaitu 53\%. Terdapat sedikit perbedaan antara laki-laki dan perempuan pada kasus ameloblastoma. Perempuan terdapat pada 37 kasus $(56,1 \%)$, lebih banyak dibandingkan laki-laki sejumlah 29 kasus $(43,9 \%)$ dan tipe histopatologis yang terbanyak ditemukan adalah plexiform sebanyak 31,8\%. Simpulan: Ameloblastoma terjadi pada periode dewasa, lebih sering pada perempuan dibandingkan laki-laki, dan didominasi tipe plexiform.
\end{abstract}

Key words: ameloblastoma, histopathology type of ameloblastoma, plexiform

\section{INTRODUCTION}

Ameloblastoma is an odontogenic tumor occurring mostly in mandible. ${ }^{1}$ This tumor arises from epithelium that plays a role in the process of tooth development, but the trigger of neoplastic transformation of the epithelium is remained unknown. ${ }^{2}$ Microscopi- cally, ameloblastoma is composed of epithelium islands in collagen connective tissue stroma. ${ }^{1}$ Ameloblastoma also has a few variations in histopathological appearance, but the most common types are follicular and plexiform. ${ }^{3}$ In most cases, ameloblastoma usually asymptomatic, grows slowly and could expand jaws. ${ }^{4}$ In the study performed 
earlier, it was mentioned that the percentage of ameloblastoma occurrence was higher in male $(52 \%)$ than in female (48\%) from 1,258 cases of ameloblastoma that were presented. ${ }^{1}$ However another study claimed that, ameloblastoma usually found in male and female with the same incidences. ${ }^{5}$ Previous study stated that there was no gender predilection in ameloblastoma cases. From 29 data of ameloblastoma cases collected in a period of 17 years (19801997), it was found that $14(48 \%)$ cases happened in female and $15(51.7 \%)$ in male. ${ }^{23}$ In Indonesia, not many studies carried out regarding distribution and frequency of ameloblastoma. Therefore, this study aimed to evaluate the distribution and frequency of ameloblastoma cases based on histopathological types and gender in January 2002 to July 2008 at Oral Surgery Outpatient Clinic of Ciptomangunkusumo General Hospital.

Ameloblastoma also described as a special form of jaw cyst. Others stated that ameloblastoma could grow from epithelial rest of developing dental root sheet and it was known as adamantine epithelioma. At the first time used the term of adamantinoma, but according to other literature the term of adamantinoma was not suitable because in this tumor there's no enamel formation and it is not stern, while others said that if there was no enamel development so the term of ameloblastoma could be used. ${ }^{1,6-8,12}$ Ameloblastoma was also defined as a basaloid tumor that has a few variations in its histopathological appearances, clinical appearances and characteristic, and radiographically it looks like multilocular cyst. ${ }^{9,10,16}$ According to the literature, the occurrence of ameloblastoma is relatively low, only about $1 \%$ of all oral tumors and cysts. ${ }^{1}$ It was stated that ameloblastoma usually has localized and persistent development and it has th ability to cause deformations or damages, while according to others, ameloblastoma is a benign tumor, but it has localized invasive characteristic and could cause minimal induction to connective tissues. ${ }^{2}$ Ameloblastoma could grow from developing dental embryonic cells. Although ameloblastoma grows slowly, it has benign characteristics, and it is a localized invasive tumor, this pathology has a tendency to become malignant. ${ }^{3,11,13}$

As described before, ameloblastoma is a tumor originated from odontogenic epithelial; however, the trigger of neoplastic transformation in the epithelial has not been revealed yet. ${ }^{1,2}$ Epithelial that involves in ameloblastoma formation could be originated from: (1) Cell rest of enamel organ, (2) Sheet of Hertwig's or Epithelial Cell Rest of Malassez, (3) The development of enamel organ, (4) Epithelial boundary of odontogenic cyst, particularly dentigerous cyst, (5) Basal cells of oral mucosa, (6) Heterotrophic epithelial from other parts of the body, particularly hypophises gland, (7) Basal cells from epithelial surface that forms jaws. ${ }^{8,10} 33 \%$ of ameloblastoma is along with follicular cyst and $10 \%-15 \%$ is along with unerupted tooth in cyst lumen. A study asserted that 108 ameloblastoma cases are along with follicular cyst or follicular structure of impacted teeth. ${ }^{1} 25 \%$ $30 \%$ of ameloblastoma is originated from follicular cysts and about $5 \%-6 \%$ of the cysts show ameloblastic proliferation. ${ }^{19}$ There is only a little part of etiology of ameloblastoma that has been understood. However, there are few supporting factors known, such as oral infection, tooth extraction, and trauma of tooth or jaws. ${ }^{10}$

In ameloblastoma, odontoblast cells that cause induction effect are not present and mature ameloblast cells are not differentiated so there is no enamel formation. Columnar and cuboideal cells around neoplastic epithelium indicate pre-ameloblast formation. ${ }^{3}$ The lesion begins in cancelous bone then extends slowly and causes resorption of bone. Together with the growth of lesion, bony expansion occurs on buccal and lingual sides. This characteristic could be a differential factor between ameloblastoma and cyst. Cyst rarely causes bony expansion in lingual side. Tumor tissues also could spread to trabecular bone without appearance of resorption. ${ }^{12-14}$ The forming lesion could be solid, microcystic, or could be one or more big cavities of cyst. Microcystic formation could be formed as a result of degenerative process in the center of epithelial islands. Lucas reported that cyst could also be developed as a result of stroma degeneration. The areas of cyst usually are separated each other by fibrous tissue stroma, and bony septum could also be observed on dry specimen. Ameloblastoma occurs in three different clinical and radiographic situations. Nevile (2002) divided ameloblastoma to: (1) Conventional solid or multicystic (about $86 \%$ of all cases), (2) Unicystic (about $13 \%$ of all cases) and (3) Peripheral (extraosseous) (about $1 \%$ of all cases). According to Regezi (2003), ameloblastoma is divided to some biological subtype that consists of: (1) Solid ameloblastoma, (2) Cystic ameloblastoma, (3) Peripheral ameloblastoma, (4) Malignant ameloblastoma, and (5) Ameloblastic carcinoma. ${ }^{8}$

Conventional solid or multicystic type of ameloblastoma rarely occurs in children under 10 years old and relatively does not occur in age 10-19 years old. The prevalence of tumor occurrence averagely happens in third and seventh decades of life and there is no significant predilection of gender. The non-painful swelling and jaw expansion are clinical appearances that found commonly. About $85 \%$ of conventional ameloblastoma occurs in mandible and more frequent in molar area in ascending ramus and about $15 \%$ of ameloblastoma occurs in maxilla, usually in posterior region. ${ }^{8}$ 
The solid type of ameloblastoma is developed when a small focus of ameloblastoma becomes a dense mass and remains as a solid form. ${ }^{9}$ Histologically, follicular form or plexiform are the forms that occur frequently while the forms of achantomatous, granular cell, desmoplastic, and basal cell type rarely occur. ${ }^{8}$ Radiographic finding of conventional solid or intraosseous type of ameloblastoma usually is multilocular radiolucent and has internal structure of radiopaque bony septa. This type of tumor has two appearances, those are "soap bubble" and "honeycombed". Cortical bone expansion usually occurs on buccal and lingual sides, and root resorption of adjacent teeth could also happen. ${ }^{8}$ Unicystic ameloblastoma occurs in young age group with the mean of age is 35 years old compared to solid type of ameloblastoma. This type of tumor found in second and third decades of life and predominantly occurs in third molar region of mandible. ${ }^{2,3}$ More that $90 \%$ of tumor occurs in mandible, usually in posterior region. ${ }^{8}$

Unicystic type of ameloblastoma could grow from various sources of odontogenic epithelium and about $20 \%$ of them are along with impacted tooth crowns that have incomplete root formation. When expansion occurs, deformity and asymmetry of face could be apparent and generally pain and paresthesia rarely occur. ${ }^{7}$ Microscopically, the lesion almost resemble to cyst with intraluminal or mural growth presents in ameloblastoma. ${ }^{3}$ When the biggest part of tumor is luminally protrusive, therefore the term of luminal ameloblastoma could be used; while when mayor cells of tumor invade fibrous wall, then the term of mural ameloblastoma is used. ${ }^{7}$ There are three variations of histopathological types of unicystic ameloblastoma. The first type is intraluminal ameloblastoma that consists of one or more ameloblastoma nodule projected from cyst boundary into cyst lumen. The nodule could be relatively small or big and fill the cyst lumen. The second type is luminal ameloblastoma where tumor is confined by the surface of cyst luminal and lesion consists of fibrous cyst wall composed of total or partial ameloblastic epithelium. The third type is mural ameloblastoma; in this type, fibrous cyst walls are infiltrated by follicular or plexiform type of ameloblastoma. ${ }^{8}$ Radiographically, it appears as a wide unilocular radiolucent around unerupted tooth crown, involves the whole ramus and expands to coronoid process or it also could appear as unilocular radiolucent in apical portion of dental root that resembles to radicular cyst. ${ }^{8,15}$ Peripheral or extraosseous ameloblastoma could occur in gingival or alveolar soft tissues and rarely in buccal mucosa. This lesion is found in advanced adult ages, usually between 40 years old until 60 years old. Peripheral ameloblastoma was originated from the rest of dental developing tissues in gingival. $^{9}$ Peripheral ameloblastoma was an infrequent lesion and the number of it is only about $1 \%$ of all ameloblastoma cases. This tumor usually shows sessile appearance or gingival pedunculated or appears as a nonulcerated and non-painful alveolar mucous lesion. This tumor occurs more often in mandible compared to in maxilla. ${ }^{8}$ Some of these lesions could grow from oral basal epithelium cells layer and extraosseous rest in dental lamina or rests of Serres. The characteristics of this tumor are benign, non-invasive to the underlying bone. Histologically, this tumor looks like intraosseous ameloblastoma that is composed of basaloid cells that resemble to carcinoma cells on skin. ${ }^{3}$ Neville mentioned that peripheral ameloblastoma has ameloblastic epithelium islands placed in lamina propria under epithelium layer. Plexiform or follicular types are the most common type occured. Radiographically, ameloblastoma is found as a lesion which shows a variation in its involvement to bone and usually is along with root resorption of adjacent teeth. ${ }^{8}$ If local excision is performed, the frequency of recurrence is low because peripheral ameloblastoma has characteristic of less invasive compared to intraosseous ameloblastoma. ${ }^{2,3}$

Ameloblastoma occurs frequently in adult, dominantly found in the fourth and fifth decades of life. The age range of incidence is also wide, from childhood until geriatric age, and it could be happen both in male or female. ${ }^{2,5}$ It is stated that ameloblastoma is more frequent in 20-49 years old group, with the average incidence occurs in the age of 39 years old. It was also mentioned that there is an ameloblastoma case found in a 6 years old child. There is no gender predilection in the occurrence of ameloblastoma. ${ }^{1}$ Molar regions are the most common areas where ameloblastoma occurs, either in mandible or maxilla. About $80 \%$ of tumors occur in mandible, with $70 \%$ of them grow in molar region and ascending ramus, $20 \%$ were found in bicuspid region, and the last $10 \%$ happen in anterior region. ${ }^{2}$ These tumors usually grow slowly and need a period of years to manifest subjective signs and symptoms. However, this tumor could grow fast and show a tendency to become malignant. ${ }^{3,11}$ The growth of tumor usually is not accompanied with pain or asymptomatic if there is no tension in nerve filament nor secondary infection. ${ }^{3,12}$ Teeth movement or malocclusion could be the early signs of ameloblastoma. ${ }^{4}$

Ameloblastoma could grow in the jaw and macroscopically this tumor causes widening or expansion in the jawbone because of its infiltration to cancelous bone. ${ }^{4,5}$ The spreading of tumor could expand bone in buccal, lingual, or palatal side. Stress could be appeared, particularly in maxillary sinus region, and it could cause lost of teeth. Tumor usually absorbs alveolar bone around dental roots and could absorb dental roots also. ${ }^{11}$ Ameloblastoma grows by 
invading soft tissues and destroying bone or causing osteoclastic resorption. Besides its invasive characteristic, ameloblastoma also has a tendency of recurring, therefore, this tumor usually considered as localized malignant tumor. ${ }^{6}$ In rare cases, tumor fragment could metastase to lungs through aspiration. ${ }^{11}$ Ameloblastoma is relatively not sensitive to radiotherapy, therefore resection surgery or hemisection are the choices of treatments. ${ }^{1}$ In solid lesion, surgical excision is needed because if curettage is performed, the tendency to recurre is as much as $50 \%$ $90 \%$. It was also stated that it would be better if ameloblastoma is not eliminated by doing simple curettage, but by doing surgical resection with the excision borders in the normal bone to prevent further possible recurrency. ${ }^{2}$ Block excision or resection generally is performed to big lesions.

\section{METHODS}

This study is retrospective descriptional observation. As subjects, this study used secondary data taken from medical records and the report book of operation result of ameloblastoma patients in Oral and Maxillofacial Surgery Clinic Cipto Mangunkusumo General Hospital in the period of January 2002-July 2008.

\section{RESULTS}

From data of ameloblastoma patients that have been collected as many as 66 cases, it was found that 31 50 years old age group had the biggest percentages of occurrence among other age groups, that was 53\% from all cases; and the histopathological type found most often was plexiform type as many as $31.8 \%$ from all cases. From 66 samples, taken from ameloblastoma patient cases data in Oral and Maxillofacial Surgery Clinic Cipto Mangunkusumo General Hospital, graphic of frequency and distribution of ameloblastoma cases based on age groups were obtained. The data showed that individuals in $<10$ years old group as many as 3 persons $(4.5 \%)$, in 10 20 years old group as many as 6 persons $(9.1 \%)$, in 21-30 years old group as many as 15 persons $(22.7 \%)$, in $31-50$ years old group as many as 35 persons $(53 \%)$, and in $>50$ years old group as many as 7 persons $(10.6 \%)$.

The data showed that distribution and frequency of ameloblastoma cases in graphic based on its histopathological types. 66 ameloblastoma cases it was obtained follicular type in 17 cases $(25.8 \%)$, plexiform type in 21 cases $(31.8 \%)$, plexiform-follicular type in 16 cases $(24.2 \%)$, plexiform-achantomatous type in 4 cases $(6.1 \%)$, and achantomatous type also in 4 cases $(6.1 \%)$. While it also found plexiform-granular type $(1.5 \%)$, follicular-granular type $(1.5 \%)$, granular-achantomatous type $(1.5 \%)$, and folliculardesmoplastic type (1.5\%), each of them has 1 case.

From 66 samples those were data from ameloblastoma patients in Oral Surgery Policlinic Cipto Mangunkusumo General Hospital it was obtained frequency distribution graphic of histopathological types of ameloblastoma based on age groups. From 66 ameloblastoma cases it was obtained frequency distribution of histopathological types based on age groups, as follows: In $<10$ years old group, the histopathological type that found most often was follicular type ( 2 cases), followed by plexiform-follicular (1 case). There was no other histopathological type found. In 10-20 years old group, the histopathological type that found most often was plexiform type (3 cases) and plexiform-follicular type ( 3 cases). There was no other histopathological type found. In 21-30 years old group, the histopathological type that found most often was follicular type (6 cases), next was plexiform type (4 cases), and then plexiformfollicular type (6 cases) and the last was achantomatous type (1 case) and granular-achanto-matous type (1case). In $31-50$ age groups, the histopathological type that found most often was plexiform type (13 cases). Besides, there were also other type found, those were plexiform-follicular type (8 cases), follicular type (7 cases), plexiform-achantomatous type ( 3 cases), achantomatous type ( 2 cases), plexiformgranular type (1 cases) dan follicular-desmoplastic type ( 1 case). In $>50$ years old group, the histopathological type that found most often was follicular type (2 cases). Besides, there were also other type found, those were plexiform type (1 case), plexiform -follicular type (1 case), plexiform-achantomatous type (1 case), achan-tomatous type (1 case) and the last was follicular-granular type (1 case).

\section{DISCUSSION}

From 66 data of cases obtained from Oral Surgery Policlinic Cipto Mangunkusumo General Hospital in the period of January 2002-July 2008, it was found that age group with the biggest number of ameloblastoma cases was 31-50 years old group with 35 cases (53\%), followed by $21-30$ years old group with 15 cases $(22.7 \%),>50$ years old group with 7 cases (10.6\%), 10 -20 years old group with 6 cases $(9.1 \%)$ and $<10$ years old group with 3 cases $(4.5 \%)$. The result of this study corresponded to analysis of Small and Waldron (1955) and Mehlisch, Dahlin and Masson (1972) of 1036 cases that asserted that ameloblastoma cases occur most frequently in 20-50 years old patients with almost half of the number were in the third and fourth decades of life. Dresser and Segal (1967) also reported the finding of ameloblastoma case in youngest age that was in 1 
month baby or less than 1 year old; it corresponded to the result of this study that found a case with age less than 1 year old.

The most common histopathological pattern was follicular and plexiform, with the result from 20 cases that found 11 cases of follicular type, 6 cases of plexiform type and 3 cases of unicystic type. It was corresponded to the result of this study that showed that both of the types was the most common finding compared to other histophatological types. However, the most common histopathological type found was plexiform type as many as 21 cases $(31.8 \%)$, followed by follicular type as many as 17 cases $(25.8 \%)$; it was not compatible with literature of Neville, Gorlin, and Soames that stated that the biggest number of histopathological type was follicular, followed by plexiform. In this study, besides the two types, there was also achantomatous type in 4 cases $(6.1 \%)$ that was compatible with classification of histopathological appearance according to Neville. The result of this study also showed the presence of combination of histopathological type as in Neville's literature (2002) that stated that big tumor often undergoes combination of microscopic patterns. The biggest number of histopathological combination type was plexiform-follicular type as many as 16 cases $(24.2 \%)$, followed by plexiform achantomatous type as many as 4 cases $(6.1 \%)$, and then plexiform granular type (1.5\%), follicular granular type (1.5\%), granular achantomatous $(1.5 \%)$, and follicular desmoplastic (1.5\%) each of them was as many as 1 case. The numbers above describes the distribution of frequency generally in each histopathological type regardless the existing age groups.

The number of each histopathological type was different between age groups. In $<10$ years old group follicular histopathological type was found most often ( 2 cases), the next was plexiform-follicular type (1 cases). While other histopathological types were not found in this age group. In 10-20 years old group it was only found two histopathological type, those were plexiform type ( 3 cases) and plexiformfollicular type (3 cases). It was different with 21-30 years old group that has more variation in its histopathological types, those were follicular type which was found most oftern ( 6 cases), followed by plexiform type (4 cases), and then plexiform-follicular type ( 3 cases), achantomatous type ( 1 case) and the last was granular-achantomatous type (1 case). In 31 -50 years old group histopathological type that found most often was plexiform (13 cases). Other histopathological types were plexiform-follicular type (8 cases), follicular type ( 7 cases), plexiformachantomatous type ( 3 cases), achantomatous type ( 2 cases), plexiform-granular type (1 case) and follicular-desmoplastic (1 case). In $>50$ years old group, the most often found was follicular type (2 cases), followed by plexiform type (1 case), plexiformfollicular (1 case), plexiform-achantomatous type (1 case), achantomatous type (1 case) and folliculargranular type (1 case). The amount of histopathological types above was observed based on each age group that has been determined.

The result above was not impossible influenced by bias because there were limitations in the amount of data got, in the place of study, and in the time of study; also data were not complete enough to be used for other study. The incompleteness of data mentioned here means PA reports were not complete enough, the storage of patients' medical records was not systematic, and there was the lack of patients' data.

\section{CONCLUSION}

From the study about distribution and frequency of ameloblastoma based on histopathological type and gender in Oral and Maxillofacial Surgery Clinic Cipto Mangunkusumo General Hospital in the period of January 2002-July 2008, it was found that: Ameloblastoma in female patients was more frequent than in male, with the percentage of female incidence was $56.1 \%$ (37 patients) and the percentage of male incidence was $43.9 \%$ (29 patients). From 66 ameloblastoma patients, there were three main histopathological types, the biggest number was plexiform type found in 21 cases $(31.8 \%)$, followed by follicular type found in 17 cases $(25.8 \%)$ and plexiform-follicular type found in 16 cases $(24.2 \%)$. From 66 ameloblastoma patients, there were some variations of histopathological type, those were plexiform-achantomatous in 4 cases $(6.1 \%)$, achantomatous in 4 cases $(6.1 \%)$, plexiform-granular in 1 case $(1.5 \%)$, and follicular-desmoplastic in 1 case $(1.5 \%)$.

\section{REFERENCES}

1. Kruger GO. Text Book of Oral Surgery. 4th ed. Saint Louis: The CV Mosby Company; 1974.

2. Laskin DM. Oral and Maxillofacial Surgery. Vol.2. Saint Louis: The CV Mosby; 1983.

3. Shafer HL. A Text Book of Oral Pathology. Philadelphia: WB Saunders; 1983.

4. Gorlin RJ, Goldman HM. Thoma's Oral Pathology. 6th ed. Vol.1. Saint Louis: The CV Mosby Company; 1970.

5. Soames JV, Southam JC. Oral Pathology. 2nd ed. USA: Oxford University Press Inc.; 1993.

6. Cawson RA. Essentials of Dental Surgery and Pathology. 5th ed. USA: Churchill Livingstone; 1991.

7. Neville BW, Damm DD. Oral and Maxillofacial 
Pathology. 2nd ed. Philadelphia: WB Saunders; 2002.

8. Ritchie AC. Boyd's Text Book of Pathology. 9th ed. United Kingdom: Lea \& Febiger; 1990.

9. Farmer ED, Lawton FE. Stone's Oral and Dental Diseases. 5th ed. Great Britain: E \& S Livingstone; 1996.

10. Bhaskar SM. Synopsis of Oral Pathology. $6^{\mathrm{t}} \mathrm{h}$ ed. USA: The CV Mosby; 1981.

11. Pharoah W. Oral Radiology, Principles and Interpretation. 5th ed. India: The CV Mosby; 2000.

12. Fonseca RJ. Oral and Maxillofacial Surgery. Vol. 5. Philadelphia: W.B Saunders. 2003.

13. Regezi JA, Sciubba JJ, Richard CK. Oral Pathology, Clinical Pathologic Correlation. 4th ed. USA: W.B Saunders; 2003.

14. Kerr DA, Ash MM. Oral Pathology. 4th ed. Philadelphia: Lea \& Febiger;1978.

15. Whaites E. Essentials of Dental radiography and Radiology. 4th ed. United Kingdom: Churchil Livingstone. 2007. 